\title{
WIELOOSIOWA ANALIZA NAPRĘŻEŃ I ODKSZTALCEŃ GUMY NA BAZIE KAUCZUKU NATURALNEGO NR
}

\begin{abstract}
Praca prezentuje znaczenie wykonywania analizy wieloosiowego stanu naprężenia i odkształcenia. Scharakteryzowano metodę i modele stosowane do analizy wieloosiowego rozciagania materiałów elastycznych. Różnorodność metod i modeli jest wynikiem braku odpowiednich unormowań. $\mathrm{Z}$ zaprezentowanych modeli oceny obciążeń i odkształceń wykorzystano model tarczowy z wycięciami. Jako materiał do badań użyto próbkę gumy naturalnej o twardości 55ShA w kształcie tarczy z 16 otworami. Model geometryczny utworzono w środowisku Autodesk Inventor. Następnie do dyskretyzacji modelu wykorzystano program MSC.Patran. Ponadto przeprowadzono analizę porównawczą MES w programie MSC.Marc. Na podstawie analizy numerycznej można stwierdzić, że pomiar grubości próbki nie jest konieczny w cyklu badawczym dla każdego punktu pomiarowego. Na podstawie przeprowadzonej analizy sformułowano wnioski o charakterze utylitarnym. Techniczne znaczenia wykonywania takich badań jest znacznie ważniejsze. Daje to bardziej wiarygodne wyniki niż popularny test dwuosiowego rozciagania. Przeszkodą w stosowaniu tych metod badań na skalę przemysłową może być większy stopień złożoności metody i konieczność zastosowania odpowiedniej aparatury badawczej.
\end{abstract}

Słowa kluczowe: MES, guma, model materiałowy, próba rozciagania

\section{Wprowadzenie}

Do podstawowych metod określających właściwości mechaniczne materiałów należy próba rozciagania. Badania takie mają na celu określenie właściwości wytrzymałościowych. Do najważniejszych można zaliczyć: wytrzymałość na rozciąganie/ściskanie/ścinanie, naprężenie przy danym wydłużeniu (dla modułu M, np. M100, M300), wydłużenie przy danej wartości naprężenia, wartości wydłużeń przy zerwaniu (maksymalnych), pomiar naprężeń i odkształceń przy odkształceniu trwałym (plastycznym). W zależności od kierunku działającego obciążenia badania na rozciąganie klasyfikuje się na jedno- i wieloosiowe. Wybór metody badania powinien odzwierciedlać najbardziej zbliżone warunki dzia-

\footnotetext{
${ }^{1}$ Autor do korespondencji/corresponding author: Jan Ziobro, Państwowa Wyższa Szkoła Zawodowa w Sanoku, ul. Mickiewicza 21, 38-500 Sanok, tel.: +48 134655981, e-mail: jziobro@pwsz-sanok.edu.pl
} 
łania w stosunku do rzeczywistego stanu obciążenia. Jeżeli na element konstrukcji działają tylko siły rozciagające lub ściskające, wówczas wystarczy przeprowadzić badanie dla jednoosiowego stanu obciążenia. Przykładami takiego stanu mogą być: elementy kratownic, pręty, belki itp. Badanie to jest stosunkowo proste, szybkie, a zastosowana aparatura jest znacznie tańsza i mniej skomplikowana niż w innym przypadku. Dlatego badanie jednoosiowego stanu obciążenia w porównaniu z innymi metodami jest najczęściej stosowane [1].

W przypadku materiałów, które $\mathrm{w}$ warunkach rzeczywistych pracują w wieloosiowych stanach naprężenia (np. folie, tkaniny, wyroby wykonane z gumy, tworzyw sztucznych i metali), najlepiej jest przeprowadzić badania, gdzie obciążenia (rozciagające, ściskające, skręcające) działają w przynajmniej dwóch osiach. Taka próba jest bardziej miarodajna i lepiej odzwierciedla możliwe zachowanie danego materiału $w$ warunkach rzeczywistych [2-4]. Istnieje wiele metod i odmian związanych z charakteryzowaniem wieloosiowego stanu obciążenia i odkształcenia materiałów. Ta różnorodność metod jest wynikiem braku odpowiedniej normy precyzującej szczegółowe warunki przeprowadzania takich badań. Jednym z nich jest dwuosiowa próba rozciagania. Kształt próbek przeznaczonych do tych badań przedstawiono na rys. 1 . W badaniach materiałów, takich jak: tkaniny i materiały skóropodobne, tworzywa polimerowe, niektóre metale, zaleca się stosować model próbki przedstawiony na rys. 1a [5]. Model próbki przedstawiony na rys. $1 \mathrm{~b}$ [6] bywa stosowany do badania elastomerów od małej do średniej odkształcalności. Na rysunku 1c przedstawiono model krzyżowy z odpowiednimi wycięciami [7, 8]. Może on być stosowany w badaniu materiałów gumowych do dużych odkształceń. Zachowanie materiałów elastycznych i hiperelastycznych, takich jak elastomery (guma), najlepiej jest opisać z zastosowaniem modelu przedstawionego na rys. 1d [9]. Charakterystykę wieloosiowego stanu naprężenie-odkształcenie panujące $\mathrm{w}$ takich wyrobach, jak: membrany, rury, tuleje, węże itp., zaleca się opisywać, stosując modele przedstawione na rys. 1a-f [10-15]. Czynnikiem powodującym odkształcenie badanej próbki jest podawane kontrolowane ciśnienie.

Analiza literatury nie dostarcza jednoznacznej odpowiedzi na temat warunków oraz właściwych i uniwersalnych metod przeprowadzania wieloosiowego rozciagania materiałów. Charakter różnic związanych ze stosowaniem typów badań i stanów obciążeń najlepiej oddają wykresy przedstawione na rys. 2. [9]. Przyjęcie ostatecznego przebiegu wykresu do opisu stałych materiałowych zaleca się dokonać po 7-10 cyklach obciążania i odciążania. Ta liczba cykli jest wymagana ze względu na występujące zjawisko Mullinsa [16]. Efektem tego jest występowanie trwałego wydłużenia gumy pod stałymi wartościami obciążeń (rys. 3.). W związku z tym po wykonaniu tych wymaganych serii obciążenieodciążenie następuje stabilizacja trwałego wydłużenia. Na rysunku 3. przedstawiono charakterystykę przemieszczeń dla jednego (początkowego) cyklu w próbie dwuosiowego rozciagania dla gumy na bazie kauczuku naturalnego NR o twardości 55 ShA. Pole zawarte pomiędzy krzywymi nazywa się pętlą histere- 
zy (rys. 3.), która określa miarę energii mechanicznej zamienionej na energię cieplna. Małym polom pętli histerezy odpowiada mniejsze nagrzewanie się wyrobu podczas jego pracy. Właściwość tę stosuje się w materiałach przeznaczonych na opony pojazdów samochodowych, pierścienie uszczelniające (O-ringi, simmeringi) itp. Zaletą stosowania materiałów o dużej histerezie jest kumulacja lub łagodzenie: drgań, wstrząsów i uderzeń, hałasu. Mają one zastosowanie w takich wyrobach, jak: amortyzatory, tłumiki drgań, warstwy antywibracyjne i wyciszające itp. Na podstawie wielkości histerezy można również prognozować ilość lub rodzaj zastosowanego napełniacza.

a)

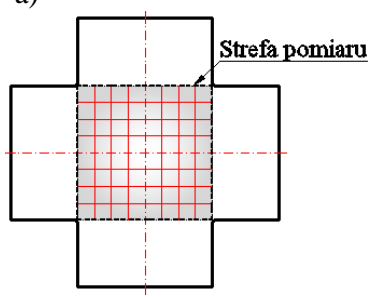

b)

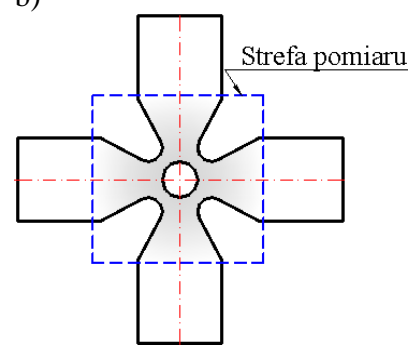

d)

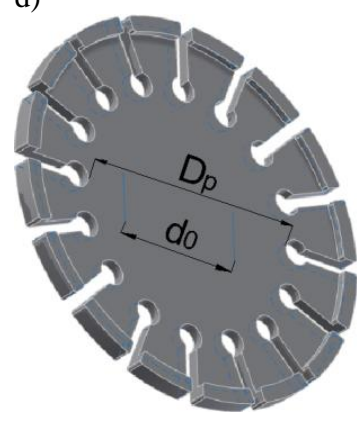

e)

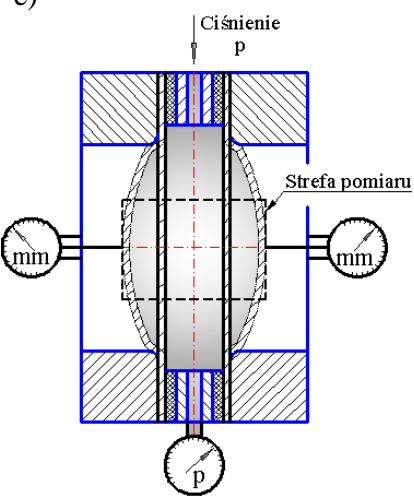

c)

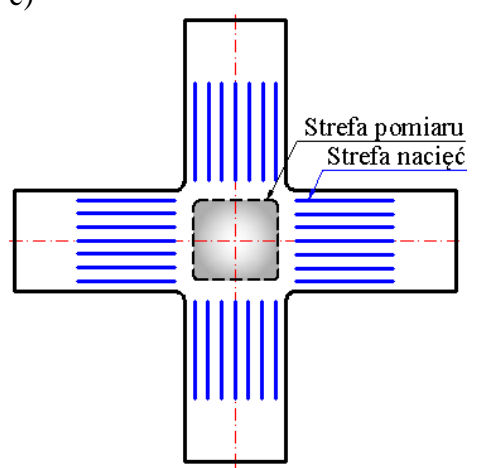

f)

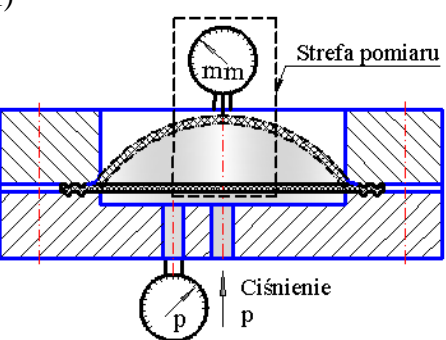

Rys. 1. Przykłady próbek stosowanych w badaniu wieloosiowego rozciągania materiałów elastycznych: a) krzyżowa krótka (tkaninowych i skóropodobnych), b) krzyżowa z wycięciami i otworem (polimerów TPE, elastomerów), c) krzyżowa z nacięciami (elastomerów, gumy), d) krążkowa $\mathrm{z}$ otworami i wycięciami, e) rurowa (elastomerów rurowych, gumy), f) membranowa (elastomery krążkowe, guma), na podstawie [5-15]

Fig. 1. Examples of samples used in the testing of multiaxial stretching elastic materials: a) crossshort (fabric and leather-like), b) cross-shaped cutouts and the hole (TPE polymers, elastomers), c) cross-shaped slits (elastomer rubber), d) disc with holes and cutouts, e) tubular (pipe elastomers, rubber), f) membrane (disc elastomers, rubber), on the base [5-15] 


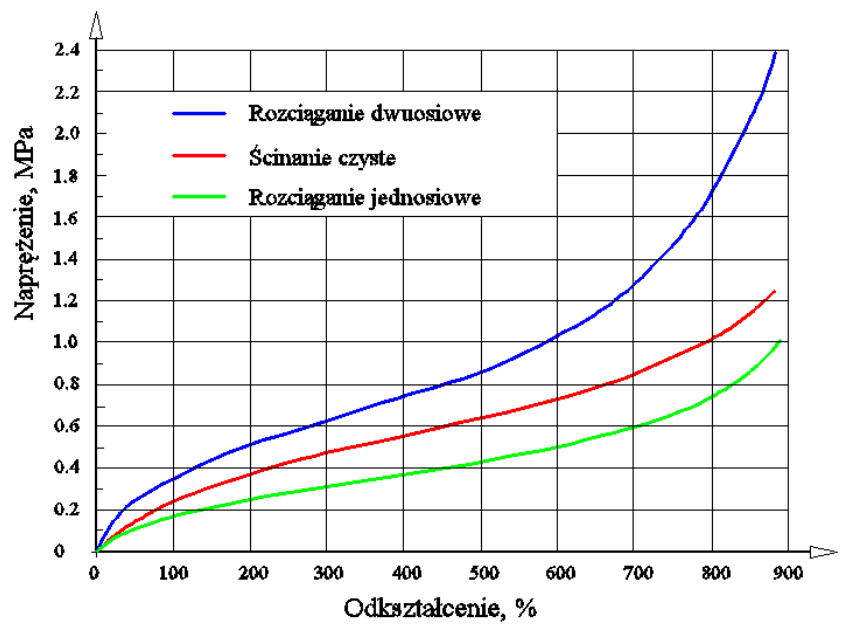

Rys. 2. Porównanie przebiegu krzywych w próbie rozciagania i ścinania, na podstawie [6]

Fig. 2. Comparison of the curves in the tensile test and shear, on the base [6]

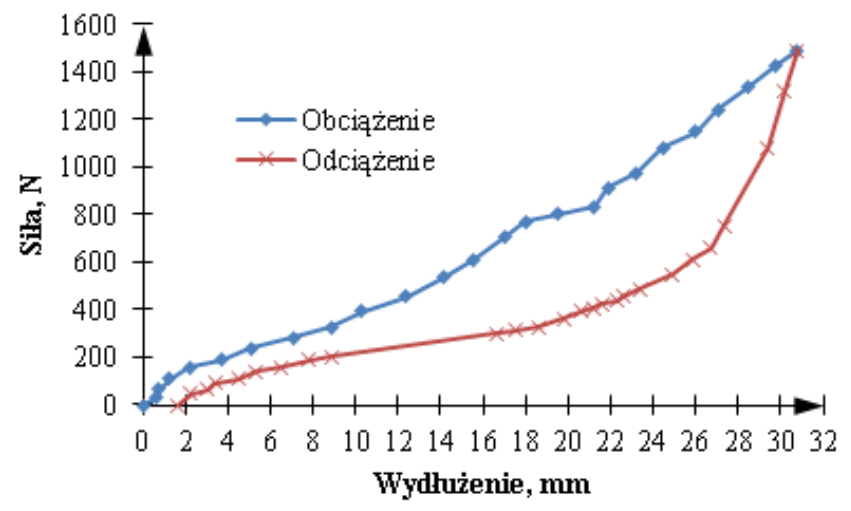

Rys. 3. Przykład pętli histerezy i zjawiska Mullinsa dla gumy NR 55

Fig. 3. An example of the hysteresis loop and the Mullins phenomenon for rubber NR 55

\section{Opis eksperymentu}

Materiałem badań jest próbka w kształcie krążka z 16 otworami i charakterystycznymi wycięciami o średnicy zewnętrznej $d=75 \mathrm{~mm}$ i grubości $g=2 \mathrm{~mm}$ (rys. 1d). Próbkę wykonano z gumy na bazie kauczuku naturalnego NR o twardości 55 ShA. Ma ona dwa specjalne liniowe znaczniki pomiarowe. Pomiędzy 
nimi wykonuje się pomiar odległości $d_{0}$ podczas przebiegu próby rozciąania. Jednocześnie dokonuje się pomiaru wartości średnicy pomiędzy otworami $D_{p}$. W celu łatwego określenia wymaganych współczynników materiałowych w modelach hiperelastyczności zaprojektowano i wykonano maszynę wytrzymałościową do badania dwuosiowego stanu rozciagania materiałów elastycznych. Ogólny jej widok przedstawiono na rys. 4a. Próbkę z wycięciami, przedstawioną na rys. $1 \mathrm{~d}$, mocuje się w 16 uchwytach maszyny (rys. 4b). Podczas obciążania wartość siły odczytuje się z dynamometru. Widok zamocowanej próbki i poddanej rozciaganiu zaprezentowano na rys. $4 \mathrm{~b}$.

a)

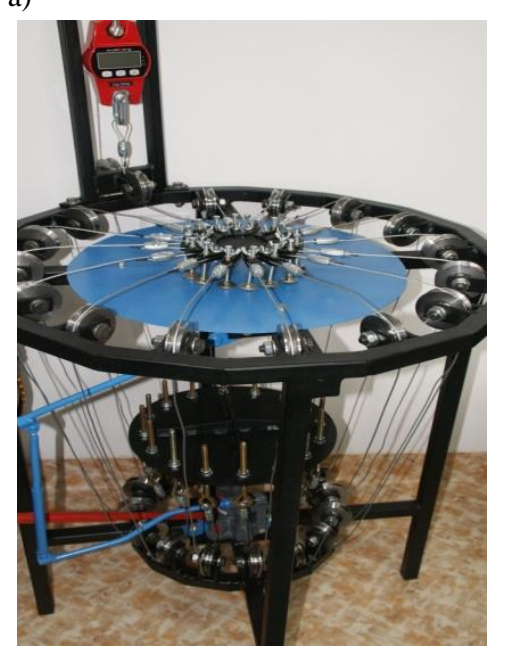

b)

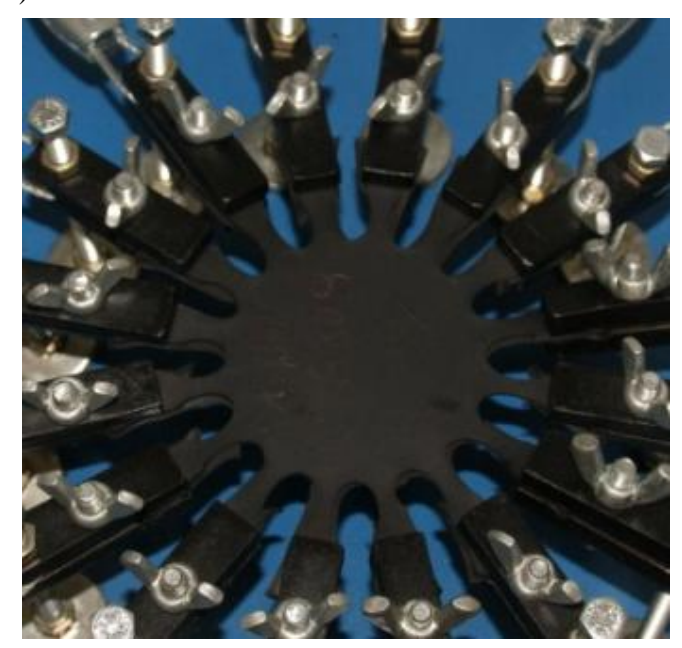

Rys. 4. Widok: a) urządzenia, b) obciążonej próbki

Fig. 4. View: a) the device, b) the loaded sample

Model geometryczny krążka 3D utworzono w programie Autodesk Inventor i wyeksportowano do programu MSC.Patran, stosując format wymiany danych Parasolid *.x_t. W systemie MSC.Patran dokonano dyskretyzacji oraz optymalizacji utworzonej struktury węzłów i elementów [17]. Tak przygotowany model wyeksportowano do programu MSC.Marc, w którym wykonano obliczenia metodą MES. Metodykę przygotowania modelu dyskretnego do obliczeń numerycznych przedstawiono w [1]. W arkuszu kalkulacyjnym Excel dokonywano niezbędnych obliczeń na podstawie doświadczalnej publikacji formuły [9]:

$$
\left.\begin{array}{c}
\sigma_{i}=\frac{16 F_{i}}{\pi D_{p} t} \\
\varepsilon_{i}=\frac{D_{i}-d_{0}}{d_{0}}
\end{array}\right\}
$$


gdzie: $i$ - numer punktu pomiarowego,

$F_{i}-$ siła w jednej lince,

$d_{0}$ - odległość początkowa pomiędzy znacznikami,

$t$ - grubość próbki,

$\varepsilon_{i}$ - odkształcenie (wydłużenie) względne,

$D_{i}$ - odległość pomiędzy znacznikami odkształconej próbki,

$D_{p}$ - średnica początkowa pomiędzy dwoma otworami.

\section{Wyniki badań i dyskusja}

Korzystając z uzyskanych wyników badań eksperymentalnych, wykonano wykresy przemieszczeń (rys. 3. i 5.) oraz przygotowano odpowiednie dane eksperymentalne do programu MSC.MARC. W środowisku MSC.Marc dokonywano dopasowywania danych eksperymentalnych do obliczeniowych matematycznych modeli materiałowych. Najlepsze dopasowanie krzywej do danych eksperymentalnych osiagnięto dzięki siedmioparametrowej postaci modelu Ogdena. Postać graficzną tego działania przedstawiono na rys. 5. W tabeli 1. podano postać analityczną oraz współczynniki materiałowe modelu Ogdena [18, 19].

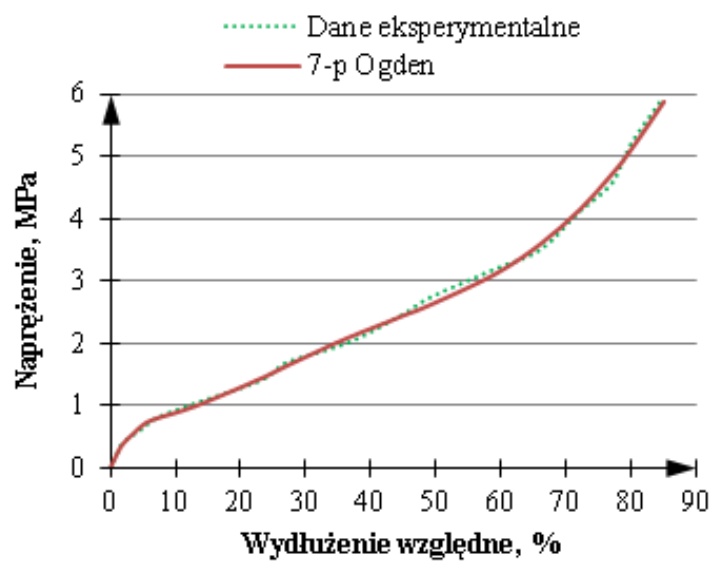

Rys. 5. Porównanie danych eksperymentalnych $\mathrm{z}$ obliczeniowymi dla gumy NR55

Fig. 5. Comparison of the experimental data with the calculation for the rubber NR 55

Zespół danych materiałowych w modelach hiperelastycznych stanowi kluczowe znaczenie $\mathrm{w}$ prowadzeniu symulacji numerycznych metodą MES. Mając ustalony model matematyczny wraz z jego wymaganymi współczynnikami, wykonano analizę porównawczą MES w aplikacji MSC.Marc. W analizie zastosowano metodę obliczeń nieliniowych oraz procedurę dużych przemieszczeń. Przyjęto warunki brzegowe identyczne $\mathrm{z}$ tymi zastosowanymi we wcześniejszym eksperymencie. Na rysunku 6a przedstawiono próbkę nieodkształconą oraz obraz przemieszczeń całkowitych próbki odkształconej. W środkowej części są widoczne liniowe znaczniki pomiarowe. Stan naprężeń rozciagających odzwierciedlono na rys. 6b. Ze względu na wieloprofilowy kształt modelu stan obciążeń 
Tabela 1. Model Ogdena i jego współczynniki

Table 1. Ogden model and his coefficients

\begin{tabular}{|c|c|c|c|}
\hline \multicolumn{3}{|c|}{ Współczynniki modelu } & Model analityczny Ogdena \\
\hline$n$ & $\alpha_{n}$ & $\mu_{n}[\mathrm{MPa}]$ & \multirow{8}{*}{ 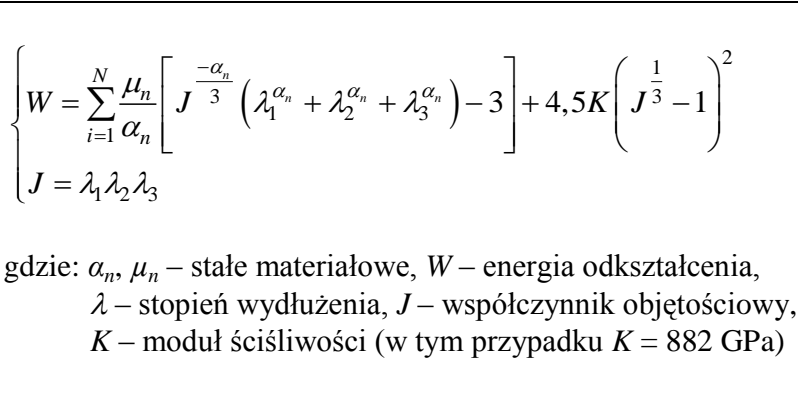 } \\
\hline 1 & 0.162 & 14.445 & \\
\hline 2 & 3.820 & -35.154 & \\
\hline 3 & -2.239 & -11.685 & \\
\hline 4 & 0.945 & 51.145 & \\
\hline 5 & 6.170 & 16.321 & \\
\hline 6 & -3.218 & 11.737 & \\
\hline 7 & -0.279 & -11.336 & \\
\hline
\end{tabular}

a)

Przemieszczenie, $\mathrm{mm}$

\begin{tabular}{|l}
$2.246 \mathrm{e}+001$ \\
$2.026 \mathrm{e}+001$ \\
$1.806 \mathrm{e}+001$ \\
$1.586 \mathrm{e}+001$ \\
$1.365 \mathrm{e}+001$ \\
$1.145 \mathrm{e}+001$ \\
$9.252 \mathrm{e}+000$ \\
$7.051 \mathrm{e}+000$ \\
$4.849 \mathrm{e}+000$ \\
$2.648 \mathrm{e}+000$ \\
$4.468 \mathrm{e}-001$
\end{tabular}

c)

Przemieszczenie w osi Z, mm

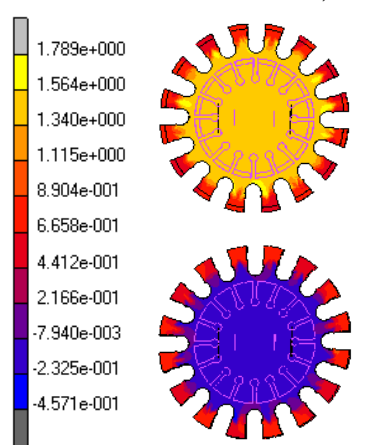

b)

Naprężenie, MPa

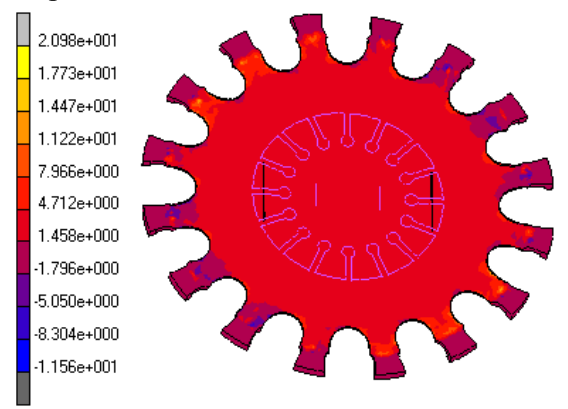

d)

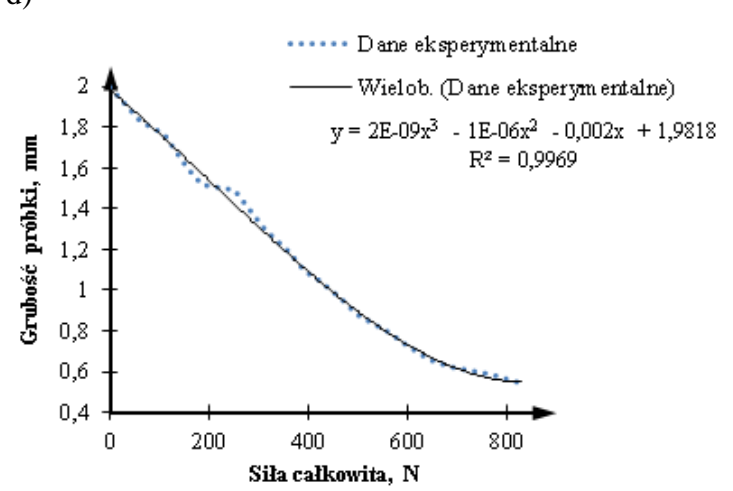

Rys. 6. Obraz: a) przemieszczeń całkowitych, b) naprężeń, c) przemieszczeń w osi $Z$ (dolna i górna strona), d) zmian krzywej grubości

Fig. 6. Image: a) total displacement, b) stress, c) displacement in the $Z$-axis (lower and upper side), d) changes in the thickness of the curve 
w tych profilach nie ma istotnego znaczenia. Rozpatrywana i ważna strefa oraz stan naprężeń znajdują się w środkowej części krążka. W wyniku rozciągania model znacznie zmniejszył swoją grubość kosztem odpowiedniego wydłużenia. $\mathrm{Na}$ rysunku 6c przedstawiono charakter zmian grubości próbki. Jej wartości można określić na podstawie map przemieszczeń warstw zewnętrznych (górnych i dolnych) w osi $Z$. Krzywą zmian grubości krążka poddanego obciążeniu układem sił odzwierciedlono na rys. 6d. Dopasowano również krzywą do danych eksperymentalnych oraz podano równanie regresji i wartość współczynnika korelacji.

Na podstawie analizy rys. 6c i d można stwierdzić, że w warstwach środkowych nie zachodzą nagłe zmiany wymiaru grubości badanego krążka. Zmiana jej wymiarów ma zatem charakter izotropowy. Jest ona uzależniona od rodzaju materiału i układu obciążającego.

\section{Podsumowanie}

Spośród przedstawionych metod służących do oceny dwuosiowego stanu odkształceń wybrano model krąż́kowy $\mathrm{z}$ wycięciami. Kierowano się przede wszystkim prostą formą określania wartości siły obciążającej i charakterystycznych odległości. Istotnym kryterium była dostępność próbek do badań. Ważne jest, aby krążki do tych badań nie zawierały żadnych widocznych wad powierzchniowych. Należy sprawdzić poprawność zamocowania oraz napięcia w linkach. Zaleca się wykonywać punkty pomiarowe w jednakowych przedziałach czasowych, co pozwoli zminimalizować błędy wskazań. W celu ograniczenia wpływu efektu Mullinsa należy wykonać $7 \div 10$ próbnych odkształceń, stopniowo zwiększając wartość siły obciążającej. Przed każdym cyklem odciążania należy zastosować chwilowy przestój. W fazie dopasowania danych eksperymentalnych do numerycznego modelu obliczeniowego metodą MES należy dążyć do uzyskania możliwie najmniejszego błędu tego działania. Na podstawie analizy numerycznej można stwierdzić, że pomiar grubości próbki nie jest konieczny w cyklu badawczym dla każdego punktu pomiarowego. Wystarczające jest podanie wartości grubości początkowej.

Istotnym utrudnieniem w wykonywaniu prób rozciagania przy obciążeniu wieloosiowym jest brak właściwych uregulowań prawnych. Wydaje się jednak, że techniczne znaczenie przeprowadzania takich badań jest o wiele ważniejsze. Daje ono bardziej miarodajne wyniki niż rozpowszechniona próba jednoosiowego rozciagania. Przeszkodą w korzystaniu z tej metody badań w skali przemysłowej może być większy stopień skomplikowania metody i zastosowania odpowiedniej aparatury badawczej. 


\section{Literatura}

[1] Ziobro J., Marciniec A.: Projektowanie form wtryskowych do elastomerów, Oficyna Wydawnicza Politechniki Rzeszowskiej, Rzeszów 2012.

[2] Krywult B., Frącz W.: Programy CAE (Computer Aided Engineering) - moduły wspomagające obliczenia konstrukcyjne wyrobów, Plastics Rev., 36 (2004), 56-59.

[3] Frącz W., Trzepieciński T.: Optymalizacja i prognozowanie deformacji wyrobów wtryskowych, Przetwórstwo Tworzyw, 16 (2010), 292-301.

[4] Frącz W.: The warpage optimization of the micro cellular injection molded part by the Taguchi method, Progressive Technologies and Materials, t. 3A, Oficyna Wydawnicza Politechniki Rzeszowskiej, Rzeszów 2009, 5-17.

[5] Deju Zhua et al.: Mechanical behaviors of Kevlar 49 fabric subjected to uniaxial, biaxial tension and in-plane large shear deformation, Composites Sci. Technol., 74 (2013), 121-130.

[6] Ognedal A.S. et al.: Experimental and numerical study on the behaviour of PVC and HDPE in biaxial tension, Mech. Materials, 54 (2012), 18-31.

[7] Hanabusaa Y. et al.: Numerical verification of a biaxial tensile test method using a cruciform specimen, J. Mat. Proc. Technol., 213 (2013), 961-970.

[8] Galliot C., Luchsinger R.H.: Uniaxial and biaxial mechanical properties of ETFE foils, Polymer Testing, 30 (2011), 356-365.

[9] MSC.Software Corporation. Nonlinear finite element analysis of elastomers. Technical Paper. Help, 103_elast_paper.pdf.

[10] Feifei Zhang et al.: Overview on constitutive modeling for hydroforming with the existence of through-thickness normal stress, J. Mat. Proc. Technol., 212 (2012), 2228-2237.

[11] Kuwabara T., Sugawarab F.: Multiaxial tube expansion test method for measurement of sheet metal deformation behavior under biaxial tension for a large strain range, Int. J. Plasticity, 45 (2013), 103-118.

[12] Schmidta A. et al.: Multiaxial deformation and failure of acrylic elastomer membranes, Sensors and Actuators A: Physical, 174 (2012), 133-138.

[13] Sasso M. et al.: Characterization of hyperelastic rubber-like materials by biaxial and uniaxial stretching tests based on optical methods, Polymer Testing, 27 (2008), 995-1004.

[14] Muammer Koç. et al.: An experimental study on the comparative assessment of hydraulic bulge test analysis methods, Materials \& Design, 32 (2011), 272-281.

[15] Yanfen Zhoua et al.: Multi-axial fatigue in magnetorheological elastomers using bubble inflation, Materials \& Design, 50 (2013), 68-71.

[16] Chagnona G. et al.: Development of new constitutive equations for the Mullins effect in rubber using the network alteration theory, Int. J. Solids Structures, 43 (2006), 6817-6831.

[17] Ziobro J., Marciniec A.: Zastosowanie narzędzi CAx w projektowaniu form wtryskowych, Polimery, 55 (2010), 877-882.

[18] MSC.Software Corp. Introduction to MSC.Marc and Mentat. MAR101 Course Notes. Help, mar101.pdf. 
[19] Ziobro J.: Analysis of the V-ribbed belt, Int. Sci. Conf. PRO-TECH-MA, Herl'any 2012, 464-471.

\title{
MULTIAXIAL STRESS AND STRAIN ANALYSIS OF THE RUBBER BASED ON THE NATURAL RUBBER NR
}

\begin{abstract}
A b s t r a ct
This paper presents the importance of performing multiaxial stress and strain state analysis. Method and presented models for the analysis of multiaxial tensile elastic materials were characterized. The variety of methods and models is the result of the lack of appropriate legislation. From the presented methods for the assessment of loads and strains the disk model with cut-outs has been used. The material of the study was the sample of rubber based on natural rubber with a hardness of 55ShA in the shape of the disc with 16 holes. In environment of the Autodesk Inventor, the geometric model has been created. Next, discretization of this model in the MSC.Patran software has been made. The comparative analysis of the FEM in the MSC.Marc application also has been done. On the basis of the numerical analysis it can be concluded that the measurement of the thickness of the sample is not necessary in the test cycle for each data point. A set of conclusions of utilitarian character has been formulated on the basis of the conducted analysis. Technical importance of carrying out such researches is much more significant. It gives more reliable results than popular uniaxial tensile test. The obstacle in applying these test methods on industrial scale can be a greater degree of complexity of the method and necessity of application of appropriate research equipment.
\end{abstract}

Key words: FME, rubber, material model, tension test

DOI:10.7862/rm.2013.19

Otrzymano/received: 10.05 .2013

Zaakceptowano/accepted: 25.07.2013 